\title{
Correction: Impact of the Nordic hamstring and hip extension exercises on hamstring architecture and morphology: implications for injury prevention
}

Bourne MN, Duhig SJ, Timmins RG, et al. Impact of the Nordic hamstring and hip extension exercises on hamstring architecture and morphology: implications for injury prevention. $\mathrm{Br} J$ Sports Med 2017;51:469-77. doi:10.1136/bjsports-2016-096130.

The competing interests statement should read:

Anthony Shield and David Opar are listed as co-inventors on a patent filed for a field test of eccentric hamstring strength (PCT/AU2012/001041.2012) as well as being shareholders in a company responsible for commercialising the device.

(C) Author(s) (or their employer(s)) 2019. No commercial re-use. See rights and permissions. Published by BMJ.

Br J Sports Med 2019;53:e2. doi:10.1136/bjsports-2016-096130corr1

D) Check for updates 